PROFESI (Profesional Islam)

Media Publikasi Penelitian; 2018; Volume 15; No 2.

Website: ejournal.stikespku.ac.id

\title{
Efektifitas Pelatihan Komunikasi Terhadap Kepuasan Pasien pada Petugas Informasi dan Pendaftaran Rumah Sakit
}

\author{
Ika Kusuma Wardani ${ }^{1^{*}}$, Mulyatim Koeswo ${ }^{2}$, Tri Wahyu Sarwiyata ${ }^{3}$ \\ ${ }^{1}$ Magister Manajemen Rumah Sakit Fakultas Kedokteran Universitas Brawijaya \\ ${ }^{2}$ Magister Manajemen Rumah Sakit Fakultas Kedokteran Universitas Brawijaya \\ ${ }^{3}$ Direktur Rumah Sakit Islam Malang \\ *Email: ikakusumawardani4@gmail.com
}

\author{
Kata Kunci \\ Komunikasi Efektif; \\ Informasi dan \\ Pendaftaran; \\ Pasien Rawat Jalan; \\ Rekam Medis;
}

\begin{abstract}
Abstrak
Kecenderungan adanya penurunan pasien rawat jalan di rumah sakitadalah terbatasnya informasi. Salah satu penyebabnya adalah faktor komunikasi petugas informasi dan pendaftaran yang kurang dipahami oleh pasien. Penelitian inibertujuan untuk mengetahui perbedaan sebelum dan sesudah pelatihan komunikasi efektif petugas terhadap kepuasan pasien. Pada penelitian ini menggunakan jenis penelitian komparatif dengan membandingkan antara petugas sebelum dan sesudah diberikan pelatihan komunikasi efektif. Pengambilan data yang digunakan pada penelitian ini menggunakan metode survey secara cross-sectionaldengan koresponden sampel berjumlah 61 pasienkemudian data dianalisis menggunakan statistik wilcoxon. Hasil penelitian menunjukan adanya peningkatan kepuasan pasien sebesar $9.9 \%$.
\end{abstract}

\section{Effectiveness of Communication Training on Patient Satisfaction To Hospital Information and Registration Officers}

\author{
Keywords \\ Effective Communication; \\ Information and \\ Registration; \\ Outpatient Installation; \\ Medical Records;
}

\begin{abstract}
The tendency of decrease in outpatients in hospitals is limited information. One reason is the communication factor of information and registration officers are poorly understood by patients. The aim is this study aims to determine the difference before and after the effective communication training officer to client satisfaction. This study, used type of comparative research by comparing the officer before and after the effective communication training. The data used in this studywas gain by using cross-sectional survey with a sample of 61 patients correspondent then the data were analyzed using the Wilcoxon statistic. The results showed an increase of $9.9 \%$ patient satisfaction
\end{abstract}

\section{PENDAHULUAN}

Menurut PMK No. 71 tahun 2003 tentang pelayanan JKN,rumah sakit adalah sarana kesehatan yang menyelenggarakan pelayanan kesehatan perorangan meliputi pelayanan promotif, preventif, kuratif dan rehabilitatif. Rumah sakit bergerak dibidang jasa pelayanan kesehatan untuk memberikan pengobatan, perawatan, serta pendidikan kesehatan bagi masyarakat. Dalam era globalisasi ini persaingan akan lebih terbuka sehingga rumah sakit dituntut untuk memberikan pelayanan prima. (Slamet Nur, 2015). Pemanfaatan fasilitas tempat tidur rumah sakit dapat dilihat BOR (Bed Occupancy Rate).

Rumah Sakit Islam Malang adalah rumah sakit swasta tipe C yang terletak di Jalan MT. Haryono No.139 Malang dengan 107 tempat tidur. Rata - rata BOR mulai Januari hingga Juli tahun 2017 sebesar 45,9\%, sedangkan perubahan jumlah kunjungan rawat jalan pada Bulan Mei ke Juni, cukup besar dibandingkan tahun sebelumnya, namun terjadi penurunan kunjungan yaitu dari 7210 menjadi 4761 kunjungan. Dari hasil Focus Group Discussion petugas rumah sakit, didapatkan bahwa turunnya angka kunjungan 
PROFESI (Profesional Islam)

Media Publikasi Penelitian; 2018; Volume 15; No 2.

Website: ejournal.stikespku.ac.id

rawat jalan tersebut disebabkan banyak hal, diantaranya kurangnya fasilitas instalasi rumah sakit, pemasaran, dan juga kepuasan pasien.

Berdasarkan hasil wawancara dan observasi langsung terhadap kegiatan pelayanan rawat jalan, didapatkan beberapa hal terkait pelayanan, diantaranya adalah pelayanan bagian informasi dan pendaftaran. Hasil survey kepuasan dari humas terhadap petugas informasi dan pendaftaran adalah 79,92\%. Hasil ini sudah cukup bagus, namun belum mencapai standar, yaitu $\geq$ $80 \%$.

Tercapainya standar kepuasan kurang $80 \%$ tersebut tak lepas dari perilaku petugas dalam melakukan pelayanan rumah sakit. Suatu pelayanan dikatakan baik ditentukan oleh jasa yang diberikan bisa memenuhi kebutuhan pasien melalui persepsi pasien tentang pelayanan yang diterima. Berdasarkan hasil penelitian (Karassavidou, 2009)menunjukkan, bahwa dimensi personal (human factor) merupakan dimensi yang penting bagi pasien.

Bagian informasi dan pendaftaran adalah salah satu bagian dari rumah sakit yang kegiatannya mengatur penerimaan dan pendaftaran pasien. Semua pasien yang akan rawat jalan dan rawat inap akan mendaftar di bagian ini. Pelayanan Informasi dan pendaftaran di Rumah Sakit Islam Malang secara umum dibagi menjadi 2 bagian, yaitu informasi pendaftaran rawat inap dan bagian informasi dan pendaftaran rawat jalan. Namun, berdasarkan alur di Rumah Sakit Islam Malang, pendaftaran selalu masuk melalui informasi pendaftaran rawat jalan terlebih dahulu. Dalam hal ini, peran petugas informasi dan pendaftaran rawat jalan menjadi sangat penting, karena merupakan pintu masuk pasien ke rumah sakit pertama kali. Bagian informasi dan pendaftaran adalah wajah dan ujung tombak yang pertama kali dilihat oleh pasien. Bagian informasi dan pendaftaran ini harus mampu menciptakan iklim positif karena para staf inilah yang menciptakan kesan pertama (First Impression) bagi pasien(Baker, 1999)

Berdasarkan hasil observasi yang dilakukan peneliti dan berdasarkan wawancara kepada pasien, didapatkan antara lain pasien mengeluh tentang keramahan petugas kurang, informasi pelayanan yang kurang dipahami pasien, sikap petugas dalam mendata pasien. Berdasarkan keluhan - keluhan yang disampaikan oleh pasien tersebut, dapat dijelaskan bahwa semua keluhan terjadi akibat kurangnya komunikasi efektif petugas informasi dan pendaftaran (IDP).

Komunikasi efektif adalah komunikasi yang terjadi apabila pesan yang disampaikan komunikator (petugas informasi dan pendaftaran) dapat diterima dengan baik oleh komunikan (pasien) sehingga tidak terjadi salah persepsi . Komunikasi efektif adalah darah dan sumber kehidupan bagi organisasi, tak terkecuali rumah sakit (Murphy, 1976). Oleh karena itu, solusi untuk mengurangi keluhan tersebut dan meningkatkan tingkat kepuasan pasien, maka dipandang perlu adanya pelatihan komunikasi terhadap petugas yang bisa menjelaskan dengan baik, sehingga informasi bisa tersampaikan dengan baik (efektif) dan tidak mengalami perbedaan persepsi pada pasien.

\section{METODE PENELITIAN}

Penelitian ini termasuk penelitian komparatif dengan pendekatan cross sectional secara insidental, yaitu dengan perlakuanterhadap petugas IDP (Informasi dan Pendaftaran). Peneliti memberikan intervensi dengan melakukan pelatihan komunikasi efektif terhadap petugas IDP (Informasi dan Pendaftaran). Sebelum pelatihan petugas, dilakukan pengukuran tingkat kepuasan pasien, selanjuntya setelah dilakukan pelatihan, peneliti melakukan pengukuran ulang terhadap tingkat kepuasan pasien. Jumlah responden pada penelitian ini digunakan 61 responden (pasien) sebelum pelatihan yang diambil menggunakan teknik insidental sampling, yang dilakukan pada Bulan September dan dilakukan evaluasi sesudah pelatihan terhadap 61 pasien tentang kepuasan pada Oktober 2017. Instrumen untuk mengukur tingkat kepuasan pasien pada penelitian ini mengacu pada Standard Operating Procedure (SOP) dan kuesioner. Analisa data dilakukan dengan membandingkan secara deskriptif tentang perbedaan tingkat kepuasan pasien antara sebelum dan sesudah pelatihan komunikasi efektif terhadap petugas IDP (Informasi dan Pendaftaran).

\section{HASIL DAN PEMBAHASAN}

Hasil penelitian menunjukan perbedaan kepuasan pasien sebelum dan sesudah pelatihan komunikasi efektif terhadap petugas IDP (Informasi dan Pendaftaran) dapat dijelaskan dari data 
khusus yang kami peroleh selama melakukan penelitian. Data khusus yang diambil adalah data keterampilan petugas dalam menyambut pasien seperti pada tabel 1. Hasil menunjukan bahwa terdapat perbedaan atau ada peningkatan rata-rata tentang ketrampilan tindakan petugas terhadap pasien sebesar $21,7 \%$, yaitu dari $61,3 \%$ sebelum menjadi $83 \%$ sesudah pelatihan.

Tabel 1. Tindakan petugas IDP (Informasi dan Pendaftaran)

\begin{tabular}{|c|c|c|c|c|c|}
\hline \multirow{2}{*}{$\begin{array}{l}\text { Tindakan Petugas } \\
\text { Informasi dan } \\
\text { Pendaftaran }\end{array}$} & \multicolumn{2}{|c|}{ Sebelum } & \multicolumn{2}{|c|}{ Sesudah } & \multirow{2}{*}{$\begin{array}{l}\text { Seli } \\
\text {-sih } \\
\%\end{array}$} \\
\hline & $\mathrm{f}$ & $\%$ & $\mathrm{f}$ & $\%$ & \\
\hline $\begin{array}{l}\text { Petugas menyambut } \\
\text { pasien dengan ber- } \\
\text { diri memberikan } \\
\text { senyum salam sapa }\end{array}$ & 20 & 32,7 & 50 & 81,9 & 49 \\
\hline $\begin{array}{l}\text { Petugas menanya- } \\
\text { kan kunjungan pa- } \\
\text { sien ke RSI }\end{array}$ & 40 & 65,5 & 56 & 91,8 & 26 \\
\hline $\begin{array}{l}\text { Petugas menanya- } \\
\text { kan tujuan peme- } \\
\text { riksaan pasien }\end{array}$ & 50 & 81,9 & 59 & 96,7 & 14,7 \\
\hline $\begin{array}{l}\text { Petugas menanya- } \\
\text { kan fasilitas } \\
\text { asuransi }\end{array}$ & 20 & 32,7 & 46 & 75,4 & 42,6 \\
\hline $\begin{array}{l}\text { Petugas melakukan } \\
\text { pencatatan data }\end{array}$ & 60 & 98,3 & 61 & 100 & 1,6 \\
\hline $\begin{array}{l}\text { Petugas membuat } \\
\text { KIB jika belum } \\
\text { punya kartu }\end{array}$ & 61 & 100 & 61 & 100 & 0 \\
\hline $\begin{array}{l}\text { Petugas menanya- } \\
\text { kan KTP/SIM jika } \\
\text { tidak membawa } \\
\text { kartu identitas }\end{array}$ & 61 & 100 & 61 & 100 & 0 \\
\hline $\begin{array}{l}\text { Petugas mengucap- } \\
\text { kan terima kasih, } \\
\text { semoga lekas sem- } \\
\text { buh }\end{array}$ & 10 & 16,3 & 44 & 72,1 & 55,7 \\
\hline $\begin{array}{l}\text { Petugas mempersi- } \\
\text { lahkan pasien me- } \\
\text { nunggu di ruang } \\
\text { tunggu }\end{array}$ & 40 & 65,5 & 55 & 90,1 & 24,5 \\
\hline $\begin{array}{l}\text { Petugas jadwal } \\
\text { dokter }\end{array}$ & 12 & 19,6 & 14 & 22,9 & 3,2 \\
\hline Rata-rata & & 61,3 & & 83 & 21,7 \\
\hline
\end{tabular}

Sumber : Data hasil kuesioner yang diolah

Hasil penelitian menunjukan pada 70table 2, bahwa setelah dilakukan pelatihan komunikasi efektif, terdapat perbedaan peningkatan kepuasan rata-rata sebesar $21,7 \%$. Peningkatan terbesar adalah kesadaran akan kemampuan petugas untuk mengucapkan terima kasih kepada pasien, yaitu dari sebesar 55,7 \% sebelum, menjadi $76,47 \%$ sesudah pelatihan. Kepuasan pasien terbesar adalah kepuasan pemberian informasi dalam pemberian pelayanan yaitu sebesar $94,12 \%$.

Tabel 2. Kepuasan pasien pada petugas IDP sebelum dan sesudah pelatihan

\begin{tabular}{lcc}
\hline \multicolumn{1}{c}{ Indikator } & $\begin{array}{c}\text { Sebelum } \\
\text { Pelatihan }\end{array}$ & $\begin{array}{c}\text { Setelah } \\
\text { Pelatihan }\end{array}$ \\
\hline $\begin{array}{l}\text { Ketepatan } \\
\text { Pemberian }\end{array}$ & $86,11 \%$ & $94,12 \%$ \\
Informasi & $88,89 \%$ & $94,12 \%$ \\
\hline $\begin{array}{l}\text { Ketepatan } \\
\text { Pelayanan } \\
\text { Pendaftaran }\end{array}$ & & \\
\hline $\begin{array}{l}\text { Kecepatan (waktu } \\
\text { tunggu antrian) }\end{array}$ & $55,6 \%$ & $76,47 \%$ \\
\hline $\begin{array}{l}\text { Kepedulian Petugas } \\
\text { dalam melayani }\end{array}$ & $75 \%$ & $88,24 \%$ \\
\hline $\begin{array}{l}\text { Keramahan, } \\
\text { penampilan, dan } \\
\text { cara komunikasi }\end{array}$ & $86,11 \%$ & $88,24 \%$ \\
\hline Rata-rata & $78,34 \%$ & $88,24 \%$ \\
\hline \begin{tabular}{l} 
Sumber : Data hasil kuesioner yang diolah \\
\hline
\end{tabular}
\end{tabular}

Berdasarkan hasil penelitian, diketahui bahwa setelah dilakukan pelatihan komunikasi efektif, kepuasan pasien dalam menerima pemberian informasi dan menerima ketepatan pelayanan meningkat menjadi sebesar $94,12 \%$. Hal ini dilatarbelakangi oleh teori yang menyebutkan bahwa dengan melakukan komunikasi efektif yaitu melakukan senyum salam sapa terhadap pasien bisa meningkatkan kepuasan pasien terhadap pelayanan kesehatan yang diterima. (Timm, 1983). Apabila komunikasi efektif dilakukan, maka pesan yang disampaikan komunikator (petugas informasi dan pendaftaran) dapat diterima dengan baik oleh komunikan (pasien) sehingga tidak terjadi salah persepsi. Jika kinerja petugas lebih tinggi dari harapan pasien, maka pasien akan mengalami kepuasan (Junaidi, 2002).

Berdasarkan data hasil kepuasan tentang keramahan dan kepedulian petugas melayani pasien juga meningkat sebesar $88,24 \%$. Hal itu sesuai teori yang menjelaskan bahwa faktor kepuasan pasien salah satunya dapat dilihat dari courtesy yaitu keramahan. Seorang petugas rumah sakit dalam melayani pasien harus 
PROFESI (Profesional Islam)

Media Publikasi Penelitian; 2018; Volume 15; No 2.

Website: ejournal.stikespku.ac.id

mengutamakan keramahan karena sikap petugas dapat berpengaruh kepada kepuasan pasien. Kepuasan pasien juga dipengaruhi oleh sikap petugas dalam menerapkan 3S (senyum, salam dan sapa) kepada pasien. Petugas harus lebih sabar dalam memberikan pelayanan kepada pasien.

Berdasarkan kecepatan antrian, terjadi peningkatan kepuasan menjadi $76,47 \%$. Hal ini terjadi dikarenakan kepatuhan petugas menanyakan tentang KIB (Kartu identitas berobat). Menurut (DEPKES, 2006) sistem pendaftaran merupakan pelayanan pertama kali yang diterima pasien saat tiba di pelayanan kesehatan. Petugas informasi dan pendaftaran merupakan gerbang utama dari suatu instansi pelayanan kesehatan. Untuk menunjang pelayanan dalam melayani pasien di tempat pendaftaran pasien. KIB (Kartu Identitas Berobat) merupakan kartu identitas milik pasien di suatu instansi pelayanan kesehatan yang berfungsi untuk mencari dokumen rekam medis milik pasien sudah berobat di instansi tersebut karena pada KIB (Kartu Identitas Berobat)terdapat nomor rekam medis pasien. Dengan kedatangan pasien ke instansi pelayanan kesehatan serta membawa KIB(Kartu Identitas Berobat) akan mempermudah petugas pendaftaran untuk mencari dokumen rekam medis pasien, maka penggunaan KIB (Kartu Identitas Berobat) diharuskan efektif dan efisien guna mempercepat pelayanan pasien di bagian pendaftaran dan menghindari penumpukan pasien yang berlebihan.

\section{SIMPULAN}

Pelatihan komunikasi efektif dapat meningkatkan keterampilan pelayanan petugas IDP (Informasi dan Pendaftaran) rawat jalan. Meningkatnya keterampilan petugas IDPrawat jalan dalam berkomunikasi yang baik dan efektif dapat menyebabkan komplain pasien menurun terhadap pelayanan. Dengan adanya komplain dari pasien terhadap pelayanan di rawat jalan yang menurun dapat menunjukan adanya kepuasan pasien yang meningkat. Dengan demikian diharapkan dapat meningkatkan tingkat loyalitas pasien terhadap pelayanan di rawat jalan Rumah Sakit Islam Malang.

\section{REFERENSI}

Baker H.K., Gary E. Powell., 1999. How Corporate Manager View Dividend. Policy, Quartely Journal OfBusiness And Economics, Vol. 38 No 2.

Junaidi S., 2002. Pengaruh Ketidakpuasan Konsumen, Karakteristik Kategori Produk, Dan Kebutuhan Mencari Variasi Terhadap Keputusan Perpindahan Merek, Jurnal Ekonomi Dan Bisnis Indonesia.

Karassavidou G.N., Papadopoulos C, 2009. Quality InNHS Hospitals: No One Knows Better Than Patients. Measur. Bus. Excel.,, 13, 1: Pp. 34-46.

Murphy H.A., Peck, C.E., 1976. Effective Business Communications, New York.

PMK No. 71 Tahun 2003 Tentang Pelayanan JKN.

Slamet Nur F.M., Af, 2015. Analysis Tangibles, Reliability,Responsiveness, Empathy Assurance And Image Of Hospital And Interest Back To Use The Service General Hospital Of Poly Ungaran Journal Of Management, 1.

Timm P., Jones, C.G., 1983. Business Communication: Getting Results, Englewood Cliffs: New Jersey. 